\title{
ENGLISH LANGUAGE LEARNING STRATEGIES USED BY SCIENCE STUDENTS
}

\author{
Nur AFNI ${ }^{1 *}$ \\ Usman KASIM ${ }^{2}$ \\ Asnawi MUSLEM ${ }^{3}$ \\ University of Syiah Kuala, Banda Aceh, Indonesia \\ ${ }^{1}$ nurafni88@mhs.unsyiah.ac.id \\ 2usman@unsyiah.ac.id \\ 3drasnawi@unsyiah.ac.id
}

Manuscript received 19 March 2019

Manuscript accepted 17 May 2019

*Corresponding author

https://doi.org/10.33736/ils.1354.2019

\begin{abstract}
Learning strategies are ways employed by learners to enhance their learning. An active use of language learning strategies helps learners to be in control of their own learning by developing language skills, and increasing confidence and motivation in learning. This study aimed to investigate the dominant language learning strategies used by science students. It focused on listening, speaking, reading, and writing strategies that was studied using descriptive qualitative method. The subjects were 56 eleventh-grade science students from the senior high boarding school of Darul Ikhsan. The questionnaire developed by Rubin and Thompson (1994) was distributed and the data was analysed by looking at the highest frequency of students' choice. The results indicated that the students employed cognitive strategies, metacognitive strategies, affective strategies, compensation strategies, and social strategies. However, the students used dominantly cognitive learning strategies across the four language skills. The findings recommended that students should be trained to use learning strategies properly. In addition, English teachers should consider the learners' strategies by asking for their intentions and use appropriate teaching methods.
\end{abstract}

Keywords: Language learning strategies, English language learning, science students 


\section{Introduction}

With globalisation, the English teaching goal in Indonesia is changing rapidly. The initial aim of teaching English is to supply learners with knowledge of English so that they can read English references. However, this aim has changed. The development in industries, transportations, communication and education in the world has forced the Indonesian government to increase the quality of human resource in Indonesia. It is obvious that to build a high quality of human resource to face the challenges, the quality of English teaching in Indonesia has to increase.

The success of passing final examination especially for English subjects has increased tremendously, and it is said to be related to the learning strategies used by students in learning English. Learning strategies are ways chosen and applied by the students to learn the English language, including ways to help themselves identify what they need to learn. O'Malley $(1985$, p. 21) confirmed that learning strategies use has considerable potential for enhancing oral skills in English. Furthermore, Skehan (1991, p. 30) believed that learning strategies influence language learning. In addition to his opinion, Skehan (1991, p. 279) also stated that individual differences are not merely about memory capacity in learning. It may be preferred styles and strategies of the learners in acquiring or learning a language.

In this study, the process of teaching and learning is narrowed to the formal education in schools. Boarding schools in Great Aceh are known to have fewer students, fewer classrooms and inadequate facility and infrastructure to support the students' learning process. However, not all boarding schools are like this; some boarding schools have enough facility and learning tools to gain positive feedback of teaching learning process, such as the Darul Ikhsan boarding school.

There are some differences between public senior high schools and boarding schools. The daily activities in boarding school are relatively more than public high schools. Teachers' attention to students is also notably higher because they have more interaction time and the number of students and teacher comparisons on boarding school is smaller, which consists at least 18 students and a maximum number is 30 students in one class. On the other hand, in general schools the number of students is around 30 up to 40 in one class so that the teacher's attention is not optimal, due to the limited time and relatively larger number of students and teachers. The classes are divided into male and female classes in boarding school, but in public schools. Boarding school implements the National standard curriculum, the Religious Affairs Department curriculum, and additional curriculum of the Boarding School. While public schools apply only the National Standard Curriculum. Educational systems in boarding schools are formal, extracurricular, specific or informal (religious, disciplinary) education, including the recitation of English vocabulary beyond the learning schedule. Students are required to practise speaking English or Arabic in all activities in the dormitory. While public schools only have formal teaching in the classroom and extracurricular activities. The time allocation in boarding school is not limited to hours of study and at lesson time. But in public schools, the use of time is very limited to teaching and learning activities.

There are some unique characteristics in the boarding school especially at Darul Ikhsan senior high boarding school, Aceh Besar, Aceh province, Indonesia. The 
researcher has been informed by some teachers who teach there that some senior high school students have won competitions such as story-telling, English debate, and both English and Arabic speech. From this positive phenomenon, the authors intended to know and discover the strategies used by students in learning English. The study objective was to investigate the dominant language learning strategies used by eleventh grade of science students in learning listening, speaking, reading, and writing skills.

Previous studies by Larsen-Freeman and Long (1991) and Dionne et al. (2003) show that women have better performance than men in second language acquisition. Similar patterns have been observed in China, Korea and the United States, among others. Linguists have tried to explain the gender differences observed in terms of language learning behaviour. Oxford (1990) also reports that women are more aware of the use of their strategies to facilitate their learning. As a result, their overall performance in mastering the language is generally better than men. Further evidence for women's dominance in language learning has been observed in other disciplines as well, including neurology and sociolinguistics. Besides, Amri (2007) surveyed learning strategies used by students in five senior high public schools in Banda Aceh and found that the students dominantly used direct strategies and the differences in terms of strategies used according to gender were also noted. However, there is still a need to investigate further on this aspect as there are other factors such as school setting that might affect the strategies used.

\section{Review of Literature}

The term "learning strategy" as used in this study refers to language learning behaviour used by students to learn and to regulate foreign language learning. "Learning strategy" also refers to what students know about the strategies they use. This knowledge is expressed in statements made by students when they are asked to rethink general aspects of their English learning. The term also refers to what students know about aspects of their language learning apart from the strategies they use, such as the general principles they can follow to learn English as a foreign language successfully, how good or bad they can use language, whether it is easy or difficult about learning English. It can be considered that such knowledge may influence the choice of learning strategies.

Learning strategies are specific approaches or techniques used by students trying to learn a second language. Language learning strategies are conscious or potentially conscious actions and students can identify them in their learning process (Cohen, 1998). Learning strategies consist of mental activities or behaviours associated with several specific stages in the whole process of language acquisition or language use (Ellis, 1994, p. 529). In other words, they can be behaviours; for example, repeating new words aloud to remember them. They can be mental; for example, using synonyms or situational contexts to deduce the meaning of new words (Ellis, 1997). Strategies can make learning easier, faster, more enjoyable, more independent, more effective, and more transferable to new situations (Oxford, 1990, p. 8). 
Chamot (2001) postulated that learning strategies are important in second language acquisition for two main reasons. The first reason is by investigating the strategies used by second language learners during the learning process, better insight into cognitive, social, and affective processes in language learning can be obtained. Secondly, less successful language learners can be taught to use the strategies used by successful learners so that they can become better language learners. He also emphasised that two main goals in language learning strategy research were to identify and compare the strategies used by more and less successful students, then give instructions to the less successful so that they helped to learn the second language more successfully.

One of the main problems in the study of foreign languages is that some students are not successful in learning English and even have low motivation in learning English. It does not mean to say that learning strategy employed by students in learning English is the only factor that influences the English learning achievement of senior high school students. Patsy and Spada $(2000$, p. 52) stated that other factors also have been identified to be relevant to language learning such as motivation, aptitudes, intelligences, learner beliefs, and age, have been found to affect second language learning. Furthermore, (Dimyati, 1999, p. 239) said that besides the variables above, concentration also affect the students' achievement. However, Oxford (1994) believed that gender, motivation, type of assignment, age and second language stage, learning style and tolerance for ambiguity, cultural background, attitudes and beliefs are factors that affect the selection of learning strategies used among students who learn a second language.

Some students learn by intensive repetition, more students learn best by trial and error. The students who come from homes where their parents read to them will discover that reading is his learning strategy to acquire new knowledge. Other students traveling to explore the world with their parents will find that doing research or experiments is a learning strategy. In this case, each student has his own learning strategy. Thus, the teacher can obtain information from the learning strategies used by students to help students expand their learning strategies and develop the way they approach language learning.

\section{Rubin's Learning Strategies Classification}

Rubin found two main types of learning strategies that contribute directly to the development of a language system built by students; they are cognitive learning strategies and metacognitive learning strategies. Cognitive learning strategies refer to the steps or operations used in learning problem solving that require direct analysis, transformation, or synthesis of learning materials (Rubin, cited in O'Malley, 1990, p. 4). He also identified six main cognitive learning strategies that contribute directly to language learning as clarification/verification by asking for examples of how to use words or phrases, repeat words to confirm understanding, as an exercise to experiment with new vocabulary sounds, repeat sentences until they are easy to say, to guess/induce inference by guessing the meaning of key words, structures, images, contexts, etc. Cognitive strategy also acts as memorisation by recording new items, saying aloud, finding mnemonics, and writing items repeatedly, as deductive 
reasoning by comparing native languages/other languages with the target language. Furthermore, this cognitive strategy is used for monitoring by improving mistakes in pronunciation itself, vocabulary, spelling, grammar, and style.

Metacognitive learning strategies are used to monitor and regulate or learn languages directly. They involve various processes such as planning, prioritising, setting goals, and self-management. The metacognitive strategy is an indirect strategy of learning a second language. This strategy emphasises the students' importance to focus on the concentration of language learning, compiling, and planning language learning, and evaluating how to learn the language. Basically, a metacognitive strategy aims to allow students to control their own knowledge. Metacognitive emphasises learning "how to learn" which is learning how to learn. Metacognitive is a general term which means "thinking about thinking". This strategy makes students aware of the process of reading and solving problems. They will become more aware of the skills needed to meet certain learning situations.

Communication strategies are less directly related to language learning because their focus is on the process of participating in conversations and getting meaning or explaining what the speaker intended. Speakers use communication strategies when they face some difficulties or misunderstandings by the co-speaker.

Social strategy is an activity carried out by students that gives them the chance to be exposed and practice their knowledge. Although these strategies provide exposure to the target language, they contribute indirectly to learning since they do not lead directly to acquiring, storing, retrieving, and using language.

\section{Oxford's Learning Strategies Classification}

Oxford (1990) proposed a new classification of learning strategy. She divided it into two main categories; direct and indirect strategies. Direct strategies are divided into memory strategies, cognitive strategies, and compensation strategies. Indirect strategies are divided into metacognitive strategies, affective strategies, and social strategies.

Direct strategies are language learning strategies that directly involve target languages (Oxford, 1990). All direct strategies require language mental processing and have different purposes. The first type of direct strategies are memory strategies, such as grouping or using imaging groups, which aim to save and retrieve new information. Memory strategies are powerful mental tools because the mind can store 100 trillion bits of information. Students who are not at the basic level of language learning usually use memory strategies. However, she said that some researchers rarely report language students using this strategy.

The second type of direct strategies are cognitive strategies are very important in learning new languages. There are four sets of cognitive strategies. They practice, receive and send messages, analyse and reason, and create structures for input and output. The strategy for practice is one of the most important parts of cognitive strategy which consists of repetition, formal practice with the sound system and writing, recognising and using formulas and patterns, combining, and practising naturalist strategies. However, the five of learning strategies in group practice, the most important thing is to practise naturally such as participating in 
conversations, reading books or articles, listening to lectures or writing letters in new languages. The receive and send a message strategy group consists of two sets of learning strategies. The first strategy helps students find the main ideas through skimming or scanning to find certain interesting details. This strategy helps learners understand quickly what they hear or read in new languages. The second strategy is used to receive and send messages that are useful for understanding incoming messages or generating outgoing messages. There are five sets of learning strategies in the analysing and reasoning strategies group. They are reasoning deductively, analysing expressions, analysing contrastively, translating, and transferring. These sets of five learning strategies concern logical analysis and reasoning as applied to various target language skills. The learners often use these learning strategies to understand the meaning of new expression or to create a new expression.

The third type of direct strategies are compensation strategies which enable students to use the new language for either comprehension or production despite limitation in knowledge. They are divided into two groups and cluster into 10 sets of learning strategies. The first group is guessing intelligently in listening and writing and other learning strategies are overcoming limitations in speaking and writing. Guessing intelligently group sometimes is called inference which has two sets of learning strategies known as using linguistic clues such as grammar, vocabulary or other target language elements and using other clues such as context, situation, text structure, personal relationship, and topic. The second group is overcoming limitation in speaking and writing learning strategies that fall into 10 learning strategies. They are switching to the mother tongue, getting help, using mime or gesture, avoiding communication partially or totally, selecting the topic, adjusting or approximating the message, coining words, and using circumlocution or synonym.

On the other hand, indirect strategies are those which provide support for language learning (Oxford, 1990, pp. 135-147). Indirect strategies are divided into metacognitive strategies, affective strategies, and social strategies. Firstly, metacognitive strategies are taken from word "metacognitive" which means beyond. Therefore, metacognitive strategies are actions which go beyond purely cognitive device and which provide a way for learners to coordinate their own learning process by using functions such as centering, arranging and planning, and evaluating learning. Centering helps learners to unite their attention and energies on certain task, activities, skills, or materials. Arranging and planning helps learners organise and plan to get the most out language learning. Evaluating helps learners check their language performance. The learners identify errors in understanding or producing the new language and evaluating their own progress in the new language; for instance, by checking to see whether his or her reading getting faster or not.

Secondly, affective strategies are applied to control emotions, attitudes about language learning, which includes lowering students' anxiety, encouraging themselves, and taking their emotional temperature. Oxford believed that a certain amount of anxiety sometimes helps learners to reach their peak performance level, but too much anxiety blocks language learning. She suggests that reducing anxiety is like having relaxed, deep breathing, or meditation. Using music and laughter are also useful to reduce the anxiety. To encourage the affective learning strategy, Oxford reminded language learners to realise themselves to use their own potential in 
learning the language. The encouragement does not always come from other people, the learners can provide their own encouragement, first, make positive statement oneself in order to feel more confident in learning the new language. Second, push oneself to take risks wisely in language learning situation. Third, reward them, give reward for particular better appearance in the new language. Taking their emotional temperature strategies helps students assess their motivational attitudes. In many cases, it relates them to language assignments. It is also helpful to discriminate negative attitude and emotion which block the language learning progress. Here, Oxford included four sets of learning strategies that explicitly listen to their bodies, use checklists, write language learning diaries, and discuss their feelings with other people's strategies.

Thirdly, social strategies are based on the view of language as a form of social that need or involve people. Here, Oxford suggested three sets of strategies. The first strategy is asking questions to help learners gain the intended meaning and understanding. This set of strategies involves asking someone, a teacher, or a native speaker, or even a friend for clarification, verification, and correction. The second strategy is to work with peers or other advanced users of the target language. This helps students not only improve students' language performance but also improve social acceptance. In addition to both learning strategies, Oxford believed that empathising with other strategies can develop the learners' perspective. Empathy can be developed more easily when language learners are aware of cultural strategies and others' thoughts and feelings.

\section{Stern's Learning Strategies Classification}

Stern (as cited in Hismanoglu, 2000) classified learning strategies into management and planning strategies, cognitive strategies, communicative-experience strategies, interpersonal strategies, and affective strategies.

Management and planning strategies are related to the learning goals of students. Learners can be responsible for developing their own learning when they get help from their teacher. In this case, students must decide what commitment to make language learning, set reasonable goals, decide on the right methodology; select appropriate resources and monitor progress, evaluate their achievements keeping in mind the goals and expectations that have been determined previously.

Cognitive strategies are the steps or operations used in learning or problem solving that require direct analysis, transformation, or synthesis of learning materials. Some cognitive strategies exhibited clarification/verification, guess/inductive inference, deductive reasoning, practice, memorisation, and monitoring.

Examples of communicative-expertential strategies are giving a signal, paraphrasing, or asking for repetition and explanation. They are techniques used by students to make a conversation take place and avoid communication disruptions.

Using interpersonal strategies, learners can monitor their own development and evaluate their own performance. Learners should be in contact with native speakers and cooperate with them. Learners must become familiar with the target culture. 
Generally, good language learners engage distinct affective strategies. Some students may feel they have failed to learn a foreign language; such as feeling strangeness, and having negative view of native speaker. These emotional problems must be cured by creating associations of positive influences on foreign languages, speakers, and on learning activities.

\section{O'Malley's Learning Strategies Classification}

O'Malley (1990, pp. 43-55) divided learning strategies into three main subcategories, they are metacognitive strategies, cognitive strategies, and social/affective strategies.

According to O'Malley, metacognitive strategies are higher order cognitive skills that require planning, monitoring, and evaluating for learning. According to Anderson, planning is a procedure for resolving conflicts between competing action statements that apply to conditional (if) clauses in the production system (cited in O'Malley, 1990, p. 44). Planning can be influenced by goals or input features that seem to be most useful for performing tasks. Learners often plan and alternate depending on the task demanded. Next, monitoring examines attention to tasks, understanding information that must be recalled when it is happening, and evaluation means checking understanding after an activity is completed. Among the main metacognitive strategies, it is possible to include advanced regulation, focused attention, selective attention, self-management, functional planning, selfmonitoring, delayed production, and self-evaluation.

Cognitive strategies are often specific to different learning activities and tasks. O'Malley (1990) also divided these strategies into several sections known as rehearsing or repeating the names of items or objects they have listened to, arranging or grouping and classifying words, terminology, or concepts according to the semantics and syntax of attributes. The next section is to conclude or use information in oral texts to guess the meaning of new linguistic items, predict results, or complete missing parts. Then, imagine or use visual images (whether produced or actual) to understand and remember new verbal information. Then, the reduction or application of rules to understand language. Part of this strategy is also to summarise what people have heard to ensure information has been stored, strategies to move or use linguistic information that are known to facilitate new learning tasks. Finally, elaboration strategies; linking ideas containing new information or integrating new ideas with known information (elaboration may be a general category for other strategies, such as imaging, summarisation, transfer and deduction.

According to O'Malley (1990), social/affective strategies represent broad groupings that involve interaction with others or ideational control over influence. The strategy that will be useful in listening to understanding is cooperation; work with colleagues to solve problems, gather information, check records, or get feedback on learning activities, question clarification or obtain from a teacher or colleague additional explanations, repeat words or examples, and speak for themselves or use mental control to convince themselves itself that learning activities will succeed or to reduce anxiety about a task. 


\section{The Importance of Learning Strategies in Language Learning and Teaching}

According to O'Malley et al. (1985, p. 23), students use learning strategies to assist with the acquisition, storage, retrieval and use of information. Oxford (1991, p. 1) explained that learning strategies are very important for language learning because they are tools for active and independent involvement which are basically useful for developing communicative competencies. He also stated that the right learning strategy resulted in greater capacity and confidence. Furthermore, similar to this point of view, Lessard (1997) asserted that language learning strategies contribute to the development of students' communicative competencies.

For the most part, Oxford (1991) and Lessard (1997) only touched on speaking skills. They did not mention the importance of learning strategies for other skills. However, Fedderholdt (1997) had an adequate explanation of the importance of learning strategies for all skills. He explained that language learners who can use a variety of language learning strategies appropriately are able to improve their language skills in a better way. In addition, he provided a detailed explanation that metacognitive strategies increase the time of organisational learning, selfmonitoring and self-evaluation. He believed that cognitive strategies including prior knowledge can help students solve new problems. Social and affective strategies involve native speakers to improve student pronunciation and ask classmates to work together to offer solutions to certain language problems. He also agreed that developing metacognitive, cognitive, and social affective skills can help students build student independence and autonomy.

The findings of these researchers provide considerable benefits in language learning and teaching even though these findings are sometimes unclear and require more investigation to explain individual differences in language learning. Many researchers say that it is not always a good learning strategy adopted by good language learners. Sometimes, good learning strategies are also applied by language learners who are not successful. There is always the possibility of language learners who use bad learning strategies or vice versa. However, the problem does not contrast with the use of learning strategies, but other factors also influence learning. Researchers do not deny this, one of which, Skehan $(1989$, p. 76$)$ stated that there is always the possibility that good learning strategies are used by bad language learners. They are still poor students for other reasons that cause them to be unsuccessful. Furthermore, Vann and Abraham (1990, p. 177) found evidence that good or successful language learners could become active users of similar learning strategies but unsuccessful learners proved to lack metacognitive strategies that would enable them to assess assignments and bring them to bear the strategies needed to solve it.

However, Ellis (1991, p. 100) classified those factors as social factor, cognitive factor, and affective factor. Social factors are external to students and concern for the relationship between students and speakers. Cognitive and affective factors are internal to students. Cognitive factors concern the nature of problemsolving strategies used by students, while affective factors involve emotional responses appearing with efforts to learn a second language. The learning strategy 
used by students in learning English is a special method in approaching problems or assignments to achieve certain goals (Brown, 2001, p. 210). Oxford (1990, p. 11) also found that when students take more responsibility, more learning takes place, both teachers and students feel more successful. In addition, Ellis (2008) assumed that the factors that influence the choice of learning strategies of students include learning factors and situational social factors. In this point, it should be emphasised that using a good learning strategy does not guarantee that bad students will also succeed in learning because other factors can also play a role in the success.

\section{Method}

A case study approach was employed to address the research questions. Gustafson (2017) stated that case studies can be defined as intensive studies of someone, a group of people or a unit that aims to generalise to several units. A case study has also been described as an intensive and systematic investigation of individuals, groups, communities or other units where researchers examine in-depth data relating to several variables (Yin, 2003). The purpose of this single case study is to explore the strategies for learning listening, speaking, reading and writing that used by students related to learning, motivation, and success in various competition activities with other public-school environments. The proposition arose when the students obtained higher scores when they were involved in competitions with other public schools and Islamic boarding schools. Some of the students who competed with other party have won the competition such as English debate, storytelling and English speech. This situation showed that there was a connection between the use of strategies to learn English with the ability of students to achieve victory and succeed in getting good English scores. In this case, the writer conducted this study with the intention of knowing the strategies used by students in English language learning.

This research was conducted using descriptive qualitative methods. Questionnaire was used in this study to collect data about learning strategies used. The research location was the senior high boarding school of Darul Ikhsan where it is located on Glee Iniem Street, Siem, Darussalam sub-district, Aceh Besar, Aceh province, Indonesia. The participants in this research were the eleventh-grade science students. The class of XI-B and XI-D were selected purposively at the boarding school. The items of questionnaire were adapted from Rubin and Thompson (1994) and four items were modified by the writer based on the research questions and the students' environment. The questionnaires were distributed to the 28 female and 28 male students of science class during their normal class session.

After the data were collected, they were checked for clarity and completeness. Then the data were coded based on the variables studied and tabulated. The data were analysed and presented in the form of frequency tables in a variety of measures of central tendency and size of dispersion that aims to understand the characteristics of sample data from the study. In the questionnaire, participants were asked to respond on a 5-point Likert scale, ranging from 5 (always done) 4 (usually done) 3 (sometimes done) 2 (rarely done) 1 (never or almost never 
done) to show their frequency using the strategies involved. The data were analysed by frequency and percentages.

\section{Results and Discussion}

The questionnaire consists of 30 items, which were included into the learning strategies in listening, speaking, reading, and writing skills.

Table 1

Percentage of strategies choice in learning listening

\begin{tabular}{ccccccc}
\hline \multirow{2}{*}{ Item No. } & \multicolumn{7}{c}{ Percentage of Students' Strategy Choice (\%) } \\
\cline { 2 - 7 } & Always & Usually & Sometimes & Rarely & Never & Total \\
\hline 1 & 58.92 & 17.85 & 12.5 & 5.35 & 5.35 & 100 \\
2 & 50.00 & 26.78 & 16.07 & 7.14 & 0.00 & 100 \\
3 & 69.64 & 5.35 & 14.28 & 7.14 & 3.57 & 100 \\
4 & 55.35 & 14.28 & 17.85 & 8.92 & 3.57 & 100 \\
5 & 51.78 & 21.42 & 0.00 & 17.85 & 8.92 & 100 \\
6 & 67.85 & 21.42 & 5.35 & 5.35 & 0.00 & 100 \\
7 & 41.07 & 26.78 & 19.64 & 3.57 & 8.92 & 100 \\
\hline
\end{tabular}

Table 1 indicates that students keep listening to get clues as to what was meant if they did not understand. The students focussed on the process of participating in a conversation and getting meaning across or clarifying what the speakers intended. This strategy is the most preferred listening strategy among the students.

Table 2

Percentage of strategies choice in learning speaking

\begin{tabular}{ccccccc}
\hline \multirow{2}{*}{ Item No. } & \multicolumn{5}{c}{ Percentage of Students' Strategy Choice (\%) } \\
\cline { 2 - 7 } & Always & Usually & Sometimes & Rarely & Never & Total \\
\hline 8 & 64.29 & 25.00 & 7.14 & 3.57 & 0.00 & 100 \\
9 & 55.36 & 14.28 & 21.43 & 8.93 & 0.00 & 100 \\
10 & 16.07 & 30.36 & 19.64 & 7.14 & 12,05 & 100 \\
11 & 51.78 & 10.71 & 17.85 & 16.07 & 3.57 & 100 \\
12 & 41.07 & 28.57 & 14.28 & 12.5 & 3.57 & 100 \\
13 & 58.92 & 17.85 & 14.28 & 7.14 & 1.78 & 100 \\
14 & 69.64 & 17.85 & 10.71 & 1.78 & 0.00 & 100 \\
\hline
\end{tabular}

Table 2 shows that the students always try to speak English in their dormitory or school. Dominantly, this shows that the students practise speaking directly so that they apply communicative-experiential strategy which is a cognitive strategy (Rubin, 1987). This strategy is the one with the highest percentage of students' choice in speaking strategies. 
Table 3

Percentage of strategies choice in learning reading

\begin{tabular}{ccccccc}
\hline \multirow{2}{*}{ Item No. } & \multicolumn{7}{c}{ Percentage of Students' Strategy Choice (\%) } \\
\cline { 2 - 7 } & always & Usually & Sometimes & Rarely & Never & Total \\
\hline 15 & 50.00 & 10.71 & 16.07 & 8.92 & 14.28 & 100 \\
16 & 37.50 & 16.07 & 21.43 & 14.28 & 10.71 & 100 \\
17 & 16.07 & 12.50 & 16.07 & 5.35 & 0.00 & 100 \\
18 & 33.92 & 28.57 & 16.07 & 17.85 & 3.57 & 100 \\
19 & 46.42 & 10.71 & 25.00 & 14.28 & 3.57 & 100 \\
20 & 48.21 & 17.85 & 14.28 & 17.85 & 1.78 & 100 \\
21 & 69.64 & 8.92 & 10.71 & 5.35 & 5.35 & 100 \\
22 & 50.00 & 12.50 & 16.07 & 12.5 & 8.92 & 100 \\
23 & 8.92 & 10.71 & 52.57 & 5.35 & 5.35 & 100 \\
24 & 69.64 & 16.07 & 7.14 & 3.57 & 3.57 & 100 \\
\hline
\end{tabular}

Table 3 shows that students tend to read the whole text first to get the big picture. This is related to skimming strategy and falls under cognitive strategy. In addition, the students always read English texts at a glance then read carefully the entire text. Students preferred to use these two strategies when they are reading.

Table 4

Percentage of strategies choice in learning writing

\begin{tabular}{ccccccc}
\hline \multirow{2}{*}{ Item No. } & \multicolumn{7}{c}{ Percentage of Students' Strategy Choice (\%) } \\
\cline { 2 - 7 } & Always & Usually & Sometimes & Rarely & Never & Total \\
\hline 25 & 25.00 & 21.42 & 33.92 & 3.57 & 10.71 & 100 \\
26 & 46.42 & 8.92 & 21.43 & 14.28 & 8.92 & 100 \\
27 & 33.92 & 48.21 & 12.50 & 1.78 & 3.57 & 100 \\
28 & 51.78 & 16.07 & 17.85 & 16.07 & 3.57 & 100 \\
29 & 12.50 & 28.57 & 23.21 & 32.14 & 3.57 & 100 \\
30 & 58.92 & 7.14 & 14.28 & 17.85 & 1.78 & 100 \\
\hline
\end{tabular}

Table 4 shows that the students always write free essay of some ideas they have in their mind. This strategy is noted with the highest percentage of students' choice in listening strategies. Besides, the students tried to use the vocabulary and grammar they already know rather than look up most of the words in a dictionary. These two strategies are the preferred strategies when they were learning writing.

To sum up, in terms of listening, it shows that 39 students (69.64\%) kept listening to get clues as to what was meant if they do not understand. The students focussed on participating in a conversation and getting meaning across or clarifying what the speaker intended. This strategy is often used by students to keep the conversation going and to avoid interrupting the communication (Rubin, 1987). This strategy is a communicative strategy which refers to cognitive strategy. Besides, most students (38 students, 67.85\%) watch English movie or listen to English songs to improve their listening ability. This activity confirms use of imagery or visual images (whether produced or actual) to understand and remember new verbal information. These results indicate that students use cognitive strategies. 
For speaking, it can be concluded that 36 students (64.29\%) rehearsed the situation in their head to make sure they can memorise dialogue for acting out in class. Moreover, 39 students (69.64\%) always tried to say in English whatever they do in their dormitory or school environment. The students practised directly in speaking; so that they apply communicative-experiential strategy, which is a cognitive strategy (Rubin, 1987).

As for reading, 37 students $(66.07 \%)$ used their knowledge of grammar to figure out unclear sentences or parts of sentences. This strategy is a metacognitive strategy. However, 39 students (69.64\%) read the whole text first to get the big picture and this skimming strategy is a cognitive strategy. In addition, 37 students used contextual clues (title, illustrations, layout, etc.) in order to figure out what the text is about. They read the text without really notice each new vocabulary. This activity shows that the students tends to employ compensation strategy.

For writing, it can be seen that 29 students $(51.78 \%)$ tried to use the vocabulary and grammar they already know rather than look up most of the words in a dictionary. This is a cognitive strategy because the students used their knowledge in writing. In addition, 33 students (58. 92\%) wrote free essays. They used several cognitive strategies: elaboration, linked ideas containing new information or integrated new ideas with information known and practised it, and used imagery and summarisation.

This study has yielded different findings as compared to other studies. Alfian (2016) found that the use of metacognitive, cognitive and social strategies was reported to be the most frequently used of all strategies. The strategies used by male participants are not different from those used by female. Students who succeed used more strategies than students who were less successful. Interview findings showed that successful language learners mostly practised the four language skills.

The effect of gender has been investigated by Ratna et al. (2001) who found that gender does not affect the learning strategies of social science students at a senior vocational school of Triyana Jakarta. Similar to this finding, Kyung (2003) found that female secondary students of Korean school showed more frequent use of all six strategies than males did.

The study done by Thu (2009) that examined language learning strategies used by successful English language learners as foreign and second languages can be compared with the results of this study. In Thu's study, data from interviews and questionnaires showed that students used various strategies to learn to listen, read, speak, write, pronounce, grammar and vocabulary. It was also found that the strategies for vocabulary learning were more than those for other language skills and the fields under investigation. Social strategies are found to be widely used by students to improve their English. In addition, reported practices are the key to increasing the four language skills as well as pronunciation, grammar, and vocabulary. 


\section{Conclusion}

The learning strategies in listening dominantly used by students are: (1) the students keep listening because they may get clues as to what was meant if they do not understand; and (2) they watch English movies or listen to English songs for improving their listening ability. The dominant learning strategies used in speaking are: (1) they rehearse the situation in their head to make sure they can memorise dialogue for acting out in class; and (2) they try to say in English whatever they do in dormitory or in the school environment. The learning strategies in reading dominantly used by students are: (1) they use their knowledge of grammar to figure out unclear sentences or parts of sentences; (2) they read the whole text first to get the big picture; (3) they use contextual clues (title, illustrations, layout, etc.) in order to figure out what the text is about. Finally, the learning strategies in writing dominantly used by students are: (1) the students try to use the vocabulary and grammar they already know rather than look up most of the words in a dictionary; and (2) they write free essay of some ideas they have in their mind.

Based on the strategies mentioned above, the students use a lot of learning strategies in learning English. They are categorised into cognitive strategies, affective strategies, metacognitive strategies, compensation strategies, and social strategies. However, cognitive strategies become the highest preferences in each skill among the students of science eleventh grade in learning English.

The findings from this study are expected to help students in finding opportunities to use learning strategies to increase their English language skills. The English teachers should also uncover the students' preferred learning strategies. They should be able to encourage the students in choosing some learning strategies which are more effective for the students in order to achieve the learning goals. Teacher should know that his/her attitude and teaching style also influence the students' interest in learning English based on the learning strategies used by students. It is important for teachers to provide opportunities to students to reflect, communicate and socialize their experiences, increase their awareness of which strategies are useful for their tasks in solving problems.

The results of this study suggested that students should be trained to use learning strategies properly. They are also expected to use memory strategies since it may activate students' right brain function because they are trained to make a story, song or rhythm and images so that a material becomes something unique, interesting, and fun. The teacher should explain to students about the benefits of compensation strategy use in learning English. Thus, the students will find it easier to memorise vocabulary. Besides, the students may use metacognitive strategies in order to get self-reflection, self-responsibility and initiative as well as goal setting and time management. This research is expected to be a reference material and useful for academics; for senior high school students, teachers, researchers, and especially for students of English education department. 


\section{References}

Alfian. (2016). The application of language learning strategies of high school students in Indonesia. Indonesian Journal of English Education, 3(2), 140-157.

Amri, M. (2007). Learning strategy used by senior high school students in learning English in Banda Aceh (a survey of senior high schools in Banda Aceh). Unpublished Thesis, Syiah Kuala University.

Brown, H. D. (2001). Teaching by principles: An interactive approach to language pedagogy. Boston, MA: Addition Wesley, Inc.

Chamot, A. U. (2001). The role of learning strategies in second language acquisition. In M. P. Breen (Ed.), Learner contributions to language learning: New directions in research (pp. 25-43). London, England: Longman.

Dionne, G., Dale, S. P., Boivin, M., \& Plomin, R. (2003). Genetic evidence for bidirectional effects of early lexical and grammatical development. Child Development, 74(2), 394-412

Dimyanti \& Mudjiono. (1999). Learning and learning strategies. Jakarta, Indonesia: PT. Rineka Cipta.

Ellis, R. (1991). Understanding second language acquisition. Hong Kong: Oxford University Press.

Ellis, R. (1994). The study of second language acquisition. Oxford, England: Oxford University Press.

Ellis, R. (2008). The study of second language acquisition (2nd ed.). Oxford, England: Oxford University Press.

Fedderholt, K. (1997). Using diaries to develop language strategies. The Language Teacher, 21(4). Retrieved from http://jalt-publications.org/old_tlt/files/98/apr /fedderholdt.html

Green, J., \& Oxford, R.L. (1995). A closer look at learning strategies, L2 proficiency, and gender. TESOL Quarterly, 29, 261-297.

Gustafson, J. (2017). Single case studies vs. Multiple case studies: A comparative study. https://pdfs.semanticscholar.org/ae1f/06652379a8cd56654096815dae801a5 9cba3.pdf

Hismanoglu, M. (2000). Language learning strategies in foreign language learning and teaching. Retrieved from http://iteslj.org/article/hismanoglu-strategies.

Kamalizad, J., \& Samuel, M. (2018). Cross context role of language proficiency in learners' use of language learning strategies. MOJES: Malaysian Online Journal of Educational Sciences, 3(1), 1-13.

Kim, K. H. (2003). Language learning strategies, learning styles, and beliefs about language learning of Korean university students. Journal of Pan-Pacific Association of Applied Linguistics, 5, 31-46.

Larsen-Freeman, D. \& Long, M. H. (1991). An introduction to second language research. London: Longman.

Lessard-Clouston, M. (1997). Language strategies: An overview for L2 teacher. The Internet TESL Journal, 3(12). Retrieved from http://iteslj.org/Articles/LessardClouston-Strategy.html 
O'Malley, J. M., \& Chamot, A. U. (1994). Learning strategies in second language acquisition. Cambridge, MA: Cambridge University Press.

O'Malley, J. M., Chamot, A. U., Stewner-Manzanares, G., Russo, R. P., \& Küpper, L. (1985). Learning strategies applications with students of English as a Second Language. TESOL Quarterly, 19(3), 557-584.

Oxford, R. L. (1990). Language learning strategies: What every teacher should know. New York: Newbury House.

Oxford, R. L. (1994). Language learning motivation: Expanding the theoretical framework. Modern Language Journal, 78, 12-28.

Oxford, R. L., \& Ehrman, M. E. (1995). Adults' language learning strategies in an intensive foreign language program in the United States. System, 23, 359-386.

Oxford, R. L., \& Nyikos, M. (1993). A factor analytic study of language learning strategy use: Interpretation from information processing theory and social psychology. Modern Language Journal, 77(1), 11-22.

Patsy, M., \& Spada, N. (2000). How languages are learned. Hong Kong: Oxford University Press.

Ratna, R. S. (2001). The effect learning styles to build learner autonomy. TEFLIN, $12(1)$.

Rubin, J. (1975). What the 'good language learner' can teach us. TESOL Quarterly, 9, 41-51.

Rubin, J. (1981). Study of cognitive processes in second language learning. Applied Linguistics, 11, 117-131.

Rubin, J., \& Thompson, I. (1994). How to become a more successful language learner. Boston, MA: Heinle \& Heinle.

Skehan, P. (1991). Individual differences in second language learning. Studies in Second Language Acquisition, 13(2), 275-296.

Stern, H. H. (1992). What can we learn from the good language learner? Canadian Modern Language Review, 31, 304-318.

Thu, T. H. (2009). Learning strategies used by successful language learners. Retrieved from https://eric.ed.gov/?id=ED507398

Yin, R. K. (2003). Case study research: Design and methods ( $2^{\text {nd }}$ ed.). Thousand Oaks, CA: Sage. 